\title{
HORSE TRICHINELLOSIS, AN UNRESOLVED PUZZLE
}

\author{
POZIO E.*, TAMBURRINI A.* \& LA ROSA G.*
}

\section{Summary :}

In spite of routine controls to detect Trichinella larvae in horsemeat, human infections due to horse-meat consumption continue to occur in France and Italy. The epidemiology of horse trichinellosis since its discovery in 1975 is outlined, addressing the possible modes of natural transmission to horses, the need to develop more sensitive methods for detecting Trichinella larvae in horses, and the economic impact of horse trichinellosis. Investigations of human outbreaks due to horse-meat consumption have implicated single cases of inadequate veterinary controls on horses imported from non-European Union countries. In particular, most cases of human infection have been attributed to horses imported from Eastern Europe, where pig trichinellosis is re-emerging and the main source of infection in horses.

KEY WORDS : horsemeat, outbreak, trichinellosis, epidemiology.

E xperimental (in Germany and Austria) and natural (in Ohio, the USA) infections of horses with Trichinella date as far back as the $19^{\text {th }}$ century (Gerlach, 1873; Csokor, 1884; Thornbury, 1897); however, the potential role of this domestic animal in the transmission of Trichinella infection to humans had been ignored until 1975, when a trichinellosis outbreak affected 89 persons who had eaten horse-meat in Italy. In the same year, another outbreak occurred in France, prompting the European Union (EU) to examine thousands of horses for the presence of Trichinella larvae, adopting the method used to detect this infection in pigs (i.e., artificial digestion of $1.0 \mathrm{~g}$ of diaphragm pillars). No natural infections in horses were detected at that time. Since 1975, human trichinellosis due to the consumption of horse-meat has accounted for $53.2 \%$ $(n=3,326)$ of the total human cases $(n=6,250)$ of trichinellosis in the EU. Specifically, these infections have occurred in France (2,296 persons in eight outbreaks) and Italy (1,030 persons in six outbreaks), and each outbreak was attributed to the consumption of meat from single horses, imported from Canada, Former Yugoslavia, Mexico, Poland and the USA (Table I). Only in

\footnotetext{
* Laboratory of Parasitology, Istituto Superiore di Sanità, viale Regina Elena 299, 00161 Rome, Italy.

Correspondence: Istituto Superiore di Sanità, viale Regina Elena 299. 00161 Rome, Italy.

Tel.: +390649902304 - Fax+390649387065 - e-mail pozio@iss.it
}

one of the 14 horses involved in these outbreaks had the routine examination at the slaughterhouse detected infection (Tamburrini et al., 2001). The failure to detect infection in the other 13 horses was, in part, due to the fact that routine examinations were conducted on small quantities of muscle tissue (i.e., $1.0 \mathrm{~g}$ ). Indeed, surveys using larger amounts of muscle tissue (i.e., 5-100 g) in tests detected Trichinella larvae in 12 horses originating from Mexico, Poland, Romania or Serbia (Table II).

\section{THE HORSE-MEAT MARKET IN THE EUROPEAN UNION}

F rance and Italy account for $71 \%$ of the horsemeat consumed in the EU (39.4 and $77.0 \times 1,000$ tonnes per year, respectively), and they are the only two countries where horse-meat is eaten raw. The large amount of horse-meat, consumed mostly raw, can, in part, explain why infected horses have resulted in outbreaks only in these two countries. Worldwide, the prevalence of infection in horse populations appears to be very low: only 25 horses have been reported to have acquired this infection since 1975 (21 detected in France and Italy and four in Mexico). In the last 25 years, approximately six million horses have been consumed in the EU; thus the 21 infected animals represent an incidence of only 3.5/1 million slaughtered horses. The fact that the infected horses were imported from countries with a high prevalence of trichinellosis in pigs and/or wildlife suggests that there is, may be, a relation between the infection in these animals and that found in horses. Specifically, three infected horses detected in 1998, two of which were sources of human infections in France and one that was detected at the slaughterhouse in Italy, had been imported from Serbia where there are areas of high prevalence of domestic trichinellosis. Five infected horses (four detected at a slaughterhouse in Mexico in 1994 and one that was a source of infection in France the same year) were from Mexico and one from Romania (imported in Italy in 1996) where domestic trichinellosis is prevalent. 


\begin{tabular}{|c|c|c|c|c|}
\hline Year & Locality (Country) & $\begin{array}{c}\text { No. of } \\
\text { human infections/death }\end{array}$ & $\begin{array}{l}\text { Country of } \\
\text { origin of the horse }\end{array}$ & Trichinella species \\
\hline 1975 & Bagnolo in Piano (It) & $89 / 0$ & Former Yugoslavia & T. britovi \\
\hline 1975 & Chatenay-Malabry $(\mathrm{Fr})$ & $125 / 0$ & East Europe & n.d. ${ }^{\mathrm{a}}$ \\
\hline 1984 & Varese (It) & $13 / 0$ & Former Yugoslavia & n.d. \\
\hline 1985 & Paris and Melun $(\mathrm{Fr})$ & $431 / 2$ & Connecticut (USA) & T. murrelli \\
\hline 1985 & Paris and 10 other foci $(\mathrm{Fr})$ & $642 / 3$ & Poland & T. spiralis \\
\hline 1986 & Salsomaggiore (It) & $300 / 0$ & Former Yugoslavia & T. britovi \\
\hline 1990 & Barletta (It) & $500 / 0$ & East Europe & T. spiralis \\
\hline 1991 & Clermont-Ferrand (Fr) & $21 / 0$ & USA & n.d. \\
\hline 1993 & Paris and 3 other foci $(\mathrm{Fr})$ & $538 / 0$ & Canada & T. spiralis \\
\hline 1994 & Provins $(\mathrm{Fr})$ & $7 / 0$ & Mexico & T. spiralis \\
\hline 1998 & Haute Garonne $(\mathrm{Fr})$ & $128 / 0$ & Serbia & T. spiralis \\
\hline 1998 & Piacenza $(\mathrm{It})^{\mathrm{b}}$ & $93 / 0$ & Poland & T. spiralis \\
\hline 1998 & Toulouse (Fr) & $404 / 0$ & Serbia & T. spiralis \\
\hline 2000 & Bitonto (It) & $36 / 0$ & Romania or Poland & T. spiralis \\
\hline
\end{tabular}

a n.d. = not determined;

${ }^{\mathrm{b}}$ The source of infection was a horse, which was found infected at the slaughterhouse in Brescia (Italy) in 1998.

Table I. - Outbreaks of human trichinellosis caused by infected horse-meat in France (Fr) and Italy (It).

\begin{tabular}{|c|c|c|c|c|c|}
\hline Year & $\begin{array}{c}\text { No. } \\
\text { of infected } \\
\text { horses }\end{array}$ & $\begin{array}{c}\text { No. of larvae/g } \\
\text { (examined muscle) }\end{array}$ & $\begin{array}{c}\text { Locality } \\
\text { where the infection } \\
\text { was detected (country) }\end{array}$ & $\begin{array}{c}\text { Country of } \\
\text { origin of the horse }\end{array}$ & Tricbinella species \\
\hline 1988 & 1 & 0.02 (biceps brachii) & Brescia (Italy) & Poland & n.d. ${ }^{a}$ \\
\hline 1989 & 1 & 0.26 (diaphragm) & Brescia (Italy) & Former Yugoslavia & n.d. \\
\hline 1994 & 4 & $0.8,1.0,1.6$ and 1.8 (diaphragm) & State of Mexico (Mexico) & Mexico & T. spiralis \\
\hline 1996 & 2 & $0.01,0.02$ (tongue) & Bordeaux (France) & Poland & n.d. \\
\hline 1996 & 1 & 11.0 (tongue) & Barletta (Italy) & Romania & T. spiralis \\
\hline 1998 & $1^{\mathrm{b}}$ & 256.0 (diaphragm) & Brescia (Italy) & Poland & T. spiralis \\
\hline 1998 & 1 & 615.0 (tongue) & Poggio Imperiale (Italy) & Serbia & T. spiralis \\
\hline 1999 & 1 & n.d. & France & Poland & T. spiralis \\
\hline
\end{tabular}

a n.d. = not determined;

${ }^{b}$ this is the same horse, which was the source of infection for the human outbreak that occurred in Piacenza (Italy) in 1998.

Table II. - Natural Trichinella infections detected in horses at the slaughterhouse during surveys (in Italy between 1988 and 1989 ; in Mexico in 1994) or during routine examinations.

\section{NATURAL TRANSMISSION OF TRICHINELLA TO HORSES}

A lthough there does not exist any epidemiological or scientific evidence of the natural modes of Trichinella transmission in horses, two hypotheses have been proposed: 1) grazing in pastures contaminated with infected rodent carcasses or pork scraps; and 2) ingesting infected flesh from pigs and wild carnivores. This second hypothesis is supported by the practice of using the carcasses of hunted or captive carnivores to fatten horses before slaughter and by the identification of larvae generally present in sylvatic carnivores (Trichinella britovi and Trichinella murrelli) from patients who acquired trichinellosis in three horsemeat outbreaks (Table II). Indeed, the use of proteins of animal origin in breeding herbivorous animals is now a common practice in many countries. Considering that the thickness of the collagen capsule increases with the age of the infection, the presence of thin capsules around the larvae in muscle tissues of the horse slaughtered in January and the presence of thick capsules in the larvae from horses slaughtered in April and October (Pozio et al., 1999) seems to support the hypothesis that horses acquire this infection in late autumn or winter, either passively (i.e., by grazing in pastures contaminated by rodent carcasses or pork scraps), or actively (i.e., by fattening horses with infected swine meat).

\section{DETECTION OF TRICHINELLA LARVAE IN HORSES}

B etween 1975 and 1990, testing for Trichinella larvae in local and imported horses was not mandatory in the EU. The mandatory testing of 
fresh horse-meat produced in or imported to the EU was established by Directive 91/497/EEC of the European Community Council. Specifically, this directive specified that testing was to consist of the artificial digestion of $1 \mathrm{~g}$ of muscle tissue, according to the procedures used to detect this infection in pigs (Council Directive $77 / 96 / \mathrm{EEC}$ ). In 1994, the minimum weight of the meat sample to be tested was increased from $1 \mathrm{~g}$ to $5 \mathrm{~g}$ (Council Directive 94/59/EEC). Indeed, Trichinella larvae in slaughtered horses have only been found when conducting artificial digestion on at least 5-10 $\mathrm{g}$ of muscles (Pozio, 2001). Serological diagnosis is not acceptable as an inspection tool in horses, since five-six months after experimental infection, circulating antibodies disappear in sera, although there are still infective muscle larvae (Soulé et al., 1989; Pozio et al., 1997). It has been demonstrated that the muscles from the head of the horse constitute the predilection site for Trichinella spiralis larvae (Pozio et al., 1999). In particular, the highest muscle burden in naturally infected animals has been found in Musculus buccinator, Lingua, Musculus levator labii maxillaris, and Musculus masseter. Compared to the diaphragm, the number of larvae per $\mathrm{g}$ is 3.5 to 6.8 times higher in Lingua, 3.5 to 6.5 times higher in M. levator labii maxillaris, and 2.5 to 4.6 times higher in $M$. buccinator. The diaphragm, which is still the most common muscle used for detecting Trichinella in horses, never ranks higher than the $6^{\text {th }}$ position among the predilection muscles for the diagnosis of this infection (Pozio et al., 1999). Published data from experimental infection in horses confirm these results (Soulé et al., 1989; Gamble et al., 1996).

\section{ECONOMIC IMPACT OF HORSE TRICHINELLOSIS}

The estimated total cost of testing for trichinellosis in slaughterhouses is 10-20 euros per horse (Boireau P., personal communication), which means that the EU spends at least 5,000,000 euros per year. It should be pointed out that the EU spends more than $99 \%$ of the funds allocated to trichinellosis control on screening those animals that are the source of less than $50 \%$ of human infections, whereas only $0.8 \%$ of the funds are used to screen horses, which are the source of more than $50 \%$ of human infections. The cost for each human infection has been estimated at 6,000 euros (Roberts et al., 1994). In the last 25 years, the total cost of the 3,300 human infections in France and Italy due to the consumption of horse-meat has been 19,800,000 euros, which is more than the total cost of human infections caused by pork or game meat. A horse carcass generally weighs $350 \mathrm{~kg}$ or more and the meat from one horse can be eaten by hundreds of people. Horse-meat intended to be consumed raw should be inspected by the most reliable methods (i.e., testing the largest amounts of tissue possible and applying highlevel quality control in the screening). Indeed, the control methods of the EU (Council Directive 77/96/EEC) can ensure the prevention of clinical trichinellosis in humans but not infection with few infective larvae.

\section{CONCLUSIONS}

T pidemiological investigations of the most recent four human outbreaks have shown that they occurred because of inadequate veterinary controls at the slaughterhouse. Horse-meat outbreaks have important consequences on public health (a high number of infected persons, some of them with a very severe symptomatology, at times resulting in death). They also have a great impact on medical costs, on the horse-meat market (a collapse in sales of horse meat after each outbreak), and in legal and administrative terms (implementation of control measures at the national and international levels, etc.) (Ancelle, 1998).

\section{REFERENCES}

ANCElle T. History of trichinellosis outbreaks linked to horse meat consumption, 1975-1998. Eurosurveillance, 1998, 3, $86-89$

CsOKOR J. Experimentelle Infektion eines Pferdes mit Trichinen. Allgemein Wien Medizin Zeitung 1884, 29, 248.

Gamble H.R., Gajadhar A.A. \& Solomon M.B. Methods for the detection of trichinellosis in horses. Journal of Food Protection, 1996, 59, 420-425.

Gerlach A.C. Die Trichinen. Schmorl and von Seefeld, Hannover, 1873, Germany.

Pozio E. The new patterns of Trichinella infection. Veterinary Parasitology, 2001, (in press).

Pozio E., Paterlini F., Pedarra C., Sacchi L., Bugarini R., GofFREDO E. \& BONI P. Predilection sites of Trichinella spiralis larvae in naturally infected horses. Journal of Helmintho$\log$, 1999, 73, 233-237.

Pozio E., Tamburrini A., Sacchi L., Gomez Morales M.A., Corona S., Goffredo E. \& La Rosa G. Detection of Trichinella spiralis in a horse during routine examination in Italy. International Journal for Parasitology, 1997, 27, 1613-1621.

Roberts T., Murrell K.D. \& Marks S. Economic losses caused by foodborne parasitic diseases. Parasitolology Today, 1994, 10, 419-423.

Soulé C., Dupouy-Camet J., Georges P., Ancelle T., Gillet J.P., Vaissaire J., Delvigne A. \& Plateau E. Experimental trichinellosis in horses: biological and parasitological evaluation. Veterinary Parasitology, 1989, 31, 19-36.

TAmburrini A., Sacchini D. \& Pozio E. An expected outbreak of human trichinellosis for the consumption of horsemeat. Parasite, 2001, 8S, (in press)

Thornbury F.J. The pathology of trichinosis. Original observations. University Medical Mag, 1897, 10, 64-79. 